\title{
阪神・淡路大震災における井戸の活用に関する研究 A STUDY ON THE PRACTICAL USE OF WELLS IN THE GREAT HANSHIN-AWAJI EARTHQUAKE DISASTER
}

\author{
安藤 元夫* \\ Motoo ANDO
}

\begin{abstract}
In The Great Hanshin-Awaji Earthquake Disaster, open spaces, trees and water resources were used beneficially as urban stock. This study focuses on wells, which played an important role while other lifelines were stopped, for example, extinguishing fires, supplying water for houses after the earthquake and so on.

The purpose of this study is clarifying the role of well, using the result of analysis about these points, through a comparison of four neighborhood units.
\end{abstract}

(i The range of well users.

(ii)The term of usage.

(iii)The purpose of use.

(iv)The way of opening to the public.

Keywords : Practical use of well. Range of well users, term of usage. Purpose of use. Way of opening to the public. Great HANSHIN-A WAJI Earthquake Disaster

井戸の活用, 利用範囲, 利用時期, 利用用途, 開放の仕方, 阪神 ·淡路大震災

\section{1. 研究の目的と調查の方法}

1995年1月17日に阪神・淡路大震災が起きた。都市值下型の地震 は，6000余人の尊い生命を㸓い多くの都市居住者の生活が長期にわ たって困難を強いられた。ライフラインで日々の生活に久くことので きない電気, 水道, ガスは途絶し, 都市機能はマヒ状態におちいっ た。しかし，そうした中で有効に働いた都市ストックがあうた。井戸 水などの水系や公園などのオープンスペース, 家屋の倒壊を防いだ樹 木等である。都市ストックのなかでも忘れかけられ消えつつあった井 戸の果たした役割は大きかった。本論文では, 井戸がいかに今回の震 災時に役立ったかを調査し，その実態を明らかにする。そして，今後 のまちづくり，とくに災害に強い都市づくりにどう活かしていくかを 考察する。震災時の都市ストックについての既往の研究は, オープン スペースや樹木が火災延焼防止等に役立ったことを明らかにしたもの が，主に造園分野から出されている。井戸などの水系ストックに関す る研究はほとんどない。

本研究は継続的な定点観測調査によって被災・被害から役立った都市 ストック, 避難生活, 立ち上がり過程と復旧·復興過程を明らかにし ていく研究の一環として取り組んでいる。調査地区の選定は, (1)被害 の大きさ，(2)専用的住宅地区か，工業·商業との混在地区かという市 街地の性格，(3)基盤整備の有無，(4)震災後復興区画整理や再開発等の
事業が行われている地区かそうでない白地地区かという4指標で，具 体的には概ね小学校区を単位とする 4 地区である1)。

(1)芦屋市精道地区（以下, 芦屋と略称）：住宅地区, 復興区画整理事 業地区が大部分, 1661棟，3378戸。

(2)長田区神楽地区（以下，神楽と略称）；ケミカルシューズによる住 工混在地区，多くが復興区画整理事業地区，905棟，2016戸。

(3)長田区二葉地区（以下，二葉と略称）：連坦商店街地区，多くが復 與再開発事業地区, 1975棟, 3313戸。

(4)須磨区西須磨地区（以下, 須磨と略称）：住宅密集地区，3本の幹 線街路事業, 2396棟, 5085戸。

井戸については参考資料等もなく, 徹底した現地観察と居住者調査 を行った。1回目の調査（1995年 3 月）は，4地区についての被災か ら立ち上がり過程の調查の一圜として, 井戸や水道管の破裂, オーブ ンスペースの利用などを調査した。2回目の調查 (12月) は, 前回調 查で把握しきれなかった井戸の発見とともに, 井戸の利用圈域, 開放 の仕方, 利用時期, 利用用途等についてヒアリングを行った。さらに 震災後の対策では2001年に行政への調査を行った。

\section{2. 井戸の利用実態と活用状況}

\section{1 井戸利用の概要}

\footnotetext{
$*$ 近畿大学理工学部建築学科 教授.工博
} 
（1）震災前, 震災後に利用できた井戸

本調查で発見できた井戸は 4 地区で2 66 個にのぼる。鹿災後の利 用状況は，「震災後利用あり」92個(35\%)，「震災後利用なし」 160 個(60\%)，「不明」14個(6\%)である。この結果をみると震災後利用 されなかった井戸が多いように思われるが，そうではない。震災前 に使用不明のものが 107 個と全体の $40 \%$ と多くを占めていたからで ある（表一1）。これは調査が不十分なためではなく, 調查を行っ ても全壊や更地で居住者が住んでいず，近所の人に聞いても震災後 に利用されていないことはわかるが，近所づきあいはしていても震 災前に井戸が利用されていたかどうかまではわからない，という答 えが多かったためである。とくに住居屋内の井戸はそれぐらい地味 な存在であったことを示している2)。

震災後利用された 92 個の井戸をみると, 元々使用されていた井戸 （73個）がほとんどであるが，以前は使用されていなかった井戸も 6 個使われている。これは, 水道の普及で井戸を利用しなくなった ものの, 埋めずに残していたことが結果的に役立ったと言える。逆 に震災以前には使用していたが震災後は利用できなかった井戸が2 8 個ある。利用できなかった理由は，家屋の倒壊 (43\%) や故障 (21 \%) であり，被害が小さければ利用できたと考えられる（表一 2)。また, 地震で水脈が変わり枯れてしまったり，反対に涌いて きたりというケース, その他水量が変わったり, 水質が悪化した井 戸もあった。

\section{（2）利用できた井戸の概要}

震災前または震災後に利用できた井戸1 20 個について, 井戸の所 有関係, 形式, 井戸の種類をみたのが図一 1 である。所有関係で は, 個人の井戸 $(68 \%)$ がほとんどで, 共同の井戸も芦屋, 須磨に みられる。

井戸の形式は，手動ポンブ式（13\%），つるべ式（5\%），電気 モーター式 $(60 \%)$ ，不明 $(22 \%)$ で電気モーター式が多い。しか し, 今回の震贸のように電気が途絶すると電気モータ一式は全く役 に立たない。井戸の種類では，住宅用の井戸（63\%）が多いが，業 務用等の井戸（36\%）もかなり使われている。とくに住商混在地区 である二葉地区では，住宅用井戸は少なく，業務用井戸の利用が目 立った。

\section{2 開放の仕方と利用範囲}

震災後の井戸の開放の仕方と利用範囲についてみる。開放の仕方 は，「開放しなかった」「知人のみに開放」「積極的に呼びかけて 開放」「張紙・看板などで開放」「公共の電波を通して開放」の 5 段階に分類した。利用範囲（利用人数）については，「個人（自分 だけ）」から「100人以上（30分程度以上の行列）まだの 6 段階に 分類した。

\section{(1) 開放の仕方}

開放の仕方をみると（表-3），「知人のみに開放」が最も多く39 件 (42\%)，次いで「積極的に呼びかけて開放」が24件（26\%）で 「開放しなかった」という人は16件（17\%）と少ない。また，「看 板・張紙などで開放」というのは 8 件（9％) と意外に少ない。

(2) 利用範囲

利用範囲 (人数) をみたのが表- 4 である。「5〜20人」が37 件 $(40 \%)$ と多く, 次いで「 $2 \cdot 3$ 人」 23 件 $(25 \%) ， 「 20 \sim 50$ 人」 12 件 (13\%) である。「50〜 100 人」「100人以上」といった
広範囲から利用される井戸も10\%程度ある。個人だけで利用された 井戸は10件(11\%) と少ない。

開放の仕方と利用範囲はほぼ比例し，開放の仕方が積極的なもの ほど利用範囲が広い（図ー2）。また「開放していない」からと

表 -1 地区別にみた井戸利用の概要

\begin{tabular}{|c|c|c|c|c|c|c|c|c|c|c|}
\hline & & & & & & & & & \multicolumn{2}{|c|}{ 件数 } \\
\hline & \multicolumn{4}{|c|}{ 震災後利用あり } & \multicolumn{4}{|c|}{ 震災後利用なし } & \multirow[b]{2}{*}{ 不明 } & \multirow[b]{2}{*}{ 計 } \\
\hline & & $\begin{array}{l}\text { 以前使 } \\
\text { 用なし }\end{array}$ & & 就 & & $\begin{array}{l}\text { 以前使 } \\
\text { 用なし }\end{array}$ & & 小計 & & \\
\hline 屋 & $\begin{array}{r}25 \\
31.6)\end{array}$ & 0 & $\begin{array}{r}1 \\
(1.3)\end{array}$ & $\begin{array}{r}26 \\
(32.9)\end{array}$ & \begin{tabular}{r|}
13 \\
$16.5)$
\end{tabular} & $\begin{array}{r}4 \\
(5.1)\end{array}$ & \begin{tabular}{r|}
39 \\
$49.4)$
\end{tabular} & $\begin{array}{r}56 \\
70.9)\end{array}$ & $\overline{0}$ & $\begin{array}{r}82 \\
103.8)\end{array}$ \\
\hline 种 & & 0 & 0 & & & 0 & 0 & & 0 & \\
\hline & $(33.3)$ & & & (33.3) & $(66.7)$ & & & $(66.7)$ & & $(100.0)$ \\
\hline 体 & $\begin{array}{r}8 \\
(53.3)\end{array}$ & 0 & $\begin{array}{r}1 \\
(6.7)\end{array}$ & $\begin{array}{r}9 \\
(60.0)\end{array}$ & 0 & 0 & $\begin{array}{r}6 \\
(40.0)\end{array}$ & $\begin{array}{r}6 \\
(40.0)\end{array}$ & 0 & $\begin{array}{r}15 \\
(100.0)\end{array}$ \\
\hline 須磨 & $\begin{array}{r}39 \\
(23.5)\end{array}$ & $\begin{array}{r}6 \\
(3.6)\end{array}$ & $\begin{array}{r}11 \\
(6.6)\end{array}$ & $\begin{array}{r}56 \\
(33.7)\end{array}$ & $\begin{array}{r}13 \\
(7.8)\end{array}$ & $\begin{array}{r}21 \\
(12.7)\end{array}$ & $\begin{array}{r}62 \\
(37.3)\end{array}$ & $\begin{array}{r}96 \\
(57.8)\end{array}$ & $\begin{array}{r}14 \\
(8.4)\end{array}$ & $\begin{array}{r}166 \\
(100.0)\end{array}$ \\
\hline It & $\begin{array}{r}73 \\
(27.4) \\
\end{array}$ & $\begin{array}{r}6 \\
(2.3) \\
\end{array}$ & $\begin{array}{r}13 \\
(4.9) \\
\end{array}$ & $\begin{array}{r}92 \\
(34.6) \\
\end{array}$ & $\begin{array}{r}28 \\
(10.5) \\
\end{array}$ & $\begin{array}{r}25 \\
(9.4) \\
\end{array}$ & $\begin{array}{r}107 \\
(40.2) \\
\end{array}$ & $\begin{array}{r}160 \\
(60.2) \\
\end{array}$ & $\begin{array}{r}14 \\
(5.3)\end{array}$ & $\begin{array}{r}266 \\
(100.0) \\
\end{array}$ \\
\hline
\end{tabular}

表ー2 震災後利用できなかった理由

\begin{tabular}{c|r|r|r|r|r|r|r}
\hline & $\begin{array}{c}\text { 家屋の } \\
\text { 倒壊 }\end{array}$ & $\begin{array}{c}\text { 持方主 } \\
\text { の不在 }\end{array}$ & 故障 & 枯れる & 濁る & 不明 & 計 \\
\hline 芦屋 & 5 & 0 & 2 & 1 & 1 & 4 & 13 \\
& $(38.5)$ & & $(15.4)$ & $(7.7)$ & $(7.7)$ & $(30.8)$ & $(100.0)$ \\
神楽 & 2 & 0 & 0 & 0 & 0 & 0 & 2 \\
& $(100.0)$ & & & & & & $(100.0)$ \\
須磨 & 7 & 2 & 4 & 0 & 0 & 0 & 13 \\
& $(53.8)$ & $(15.4)$ & $(30.8)$ & & & 1 & $(100.0)$ \\
\hline 計 & 12 & 2 & 6 & 1 & 1 & 4 & 28 \\
& $(42.9)$ & $(7.1)$ & $(21.4)$ & $(3.6)$ & $(3.6)$ & $(14.3)$ & $(100.0)$ \\
\hline
\end{tabular}

注 : 二葉地区は該当する井戸がないので表記していない

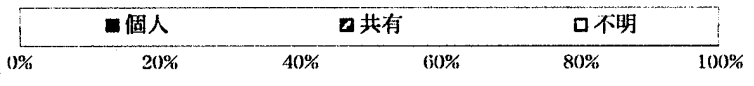

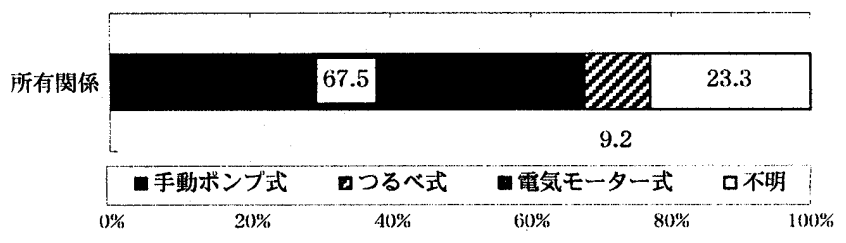

井留形式

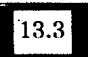
60.0

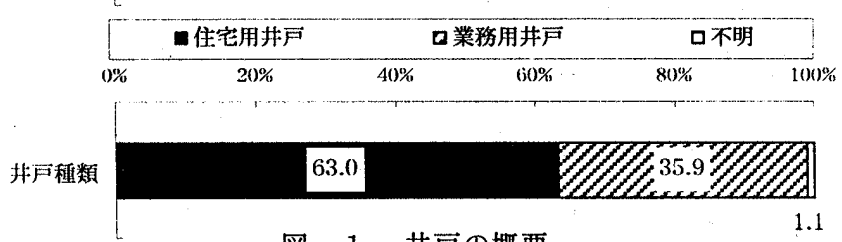

図-1 井戸の概要

表一 3 地区別開放の仕方

\begin{tabular}{|c|c|c|c|c|c|c|c|}
\hline & 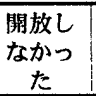 & $\begin{array}{c}\text { 知人の } \\
\text { みに開 } \\
\text { 放 }\end{array}$ & $\begin{array}{c}\text { 䄼極的に } \\
\text { 㭔びかけ } \\
\text { て開放 }\end{array}$ & $\begin{array}{c}\text { 㖘紙·看 } \\
\text { 板などで } \\
\text { 開放 }\end{array}$ & $\begin{array}{l}\text { 公共の電 } \\
\text { 波等を使 } \\
\text { つて開放 }\end{array}$ & 不明 & 計 \\
\hline 声屋 & $\begin{array}{r}5 \\
(19.2)\end{array}$ & $\begin{array}{r}9 \\
(34.6)\end{array}$ & $\begin{array}{r}9 \\
(34.6)\end{array}$ & $\begin{array}{r}3 \\
(11.5)\end{array}$ & 0 & 0 & $\begin{array}{r}26 \\
(100.0)\end{array}$ \\
\hline 一葉 & & $\begin{array}{r}2^{*} \\
(20.0)\end{array}$ & $\begin{array}{r}5 \\
(50.0)\end{array}$ & $\begin{array}{r}1 \\
(10.0)\end{array}$ & $\begin{array}{r}2 \\
(20.0)\end{array}$ & 0 & $\begin{array}{r}10 \\
(100.0)\end{array}$ \\
\hline 䫉委 & $\begin{array}{r}10 \\
(17.9)\end{array}$ & $\begin{array}{r}28 \\
(50.0) \\
\end{array}$ & $\begin{array}{r}12 \\
(21.4)\end{array}$ & $\begin{array}{r}5 \\
(8.9) \\
\end{array}$ & 0 & $\begin{array}{r}1 \\
(1.8)\end{array}$ & $\begin{array}{r}56 \\
(100.0)\end{array}$ \\
\hline 詁 & $\begin{array}{r}15 \\
(16.3)\end{array}$ & $\begin{array}{r}39 \\
(42.4)\end{array}$ & $\begin{array}{r}26 \\
(28.3)\end{array}$ & $\begin{array}{r}9 \\
(9.8)\end{array}$ & $\begin{array}{r}2 \\
(2.2)\end{array}$ & $\begin{array}{r}1 \\
(1.1)\end{array}$ & $\begin{array}{r}92 \\
(100.0)\end{array}$ \\
\hline
\end{tabular}

注 : 神楽地区の井戸は 1 個だけのため二葉地区に含む（*印） 
いって個人だけの利用とはかぎらない。持主の不在（避難など） で，周りの住民が断りなく利用している例もある。「個人」の利用 だった10件の井戸も，そのほとんどは開放を拒んだのではなく理由 がある場合が多い。例えば「周りの人は避難のためいなかった」

「井戸が家の中にあったため開放しにくかった」「すく避難したた め利用し始めたのがずっとあとになり，開放するほどの状況ではな かった」などである。

\section{3 利用の時期と用途}

(1) 利用時期

利用時期は「当日」「2・3日後」「1週間以内」「1月末」， 2 月以降は上・中・下旬に分けた。これは，震災直後はとくに水が 重要で, 当日, または $2 \cdot 3$ 日後から利用できた井戸は重要な意味 があると考えられ細かく分類した。

表一 5 をみると, 3 割強の 31 個の井戸が震災当日から利用されて いる。震災から 1 週間以内には， 7 割以上の井戸が利用され始めて いて，とくに二葉地区では 9 割（9 個）が 1 週間以内に利用されて いる。これは, 電気が早く復旧したこと（電気モーター式の井戸） と関連する。

表ー6で利用し始めることができた理由をみると，「電気がきた から」が29個で多い。しかし, 震災直後に電気がこなかったりモー ターの故障などで使えなかったため, 手動ポンプ式やつるべ式に変 えて利用した井戸が14個あった。「今どきつるべ式の井戸なんて古 い」というイメージがあるが, 元々つるべ式や手動ポンブ式で使わ れていた井戸も10個あった。それらのほとんどが, 給水車が来れな い震災直後の段階から利用できた。これは, 電気がこなくても利用 できたということで大きな意味をもつ。現代社会は普段は便利で も，災害時に役立たないものが多い。井戸に関していえば，普段は 便利な電気モーター式で利用しても, 何かあった時にはつるべ式で 利用できる工夫と設備を整えておく必要がある。また例数は少ない が「ガレキを撤去したから」や「修理したから」利用できた井戸も ある。そのほか「水が湧いてきたから」「風吕の残り湯がなくなっ たから」「井戸があることに気付いたから」と様々である。

表一 7 で利用時期と利用範囲の関係をみると, 利用時期に関係な く「 $5 \sim 20$ 人」の利用が一番多い。震災当日では, 個人の利用から 100 人以上の利用まで幅がみられる。1月末まで件数は隇っていく が同じ傾向である。

2 月になってから利用し始める井戸はさすがに少ない。しかし個 人の利用だけでなく，行列ができるほどの利用例もある。 2 月に なっても多くの地区で水道はまだ復旧していない。井戸水が依然必

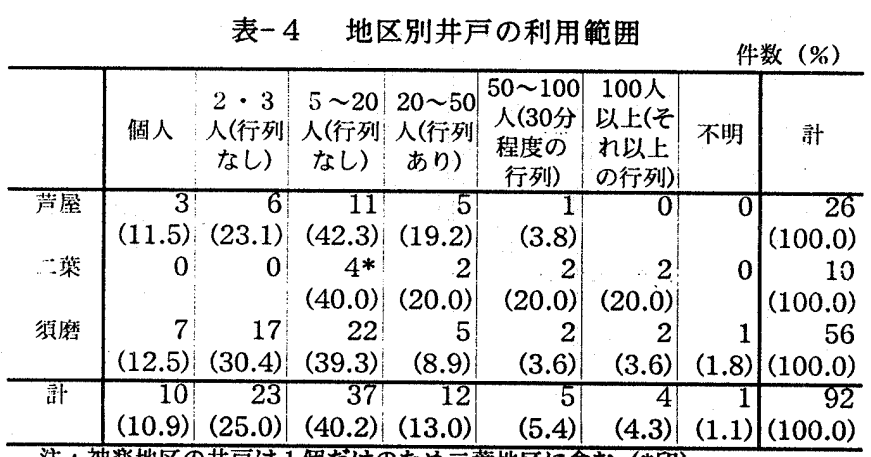

注 : 神楽地区の并戸は1 個たけのため二葉地区に含む(*印)
要な存在だったことがわかる。

\section{(2) 利用用途}

震災前, 震災後の井戸の利用用途をみたのが図ー 3 である。

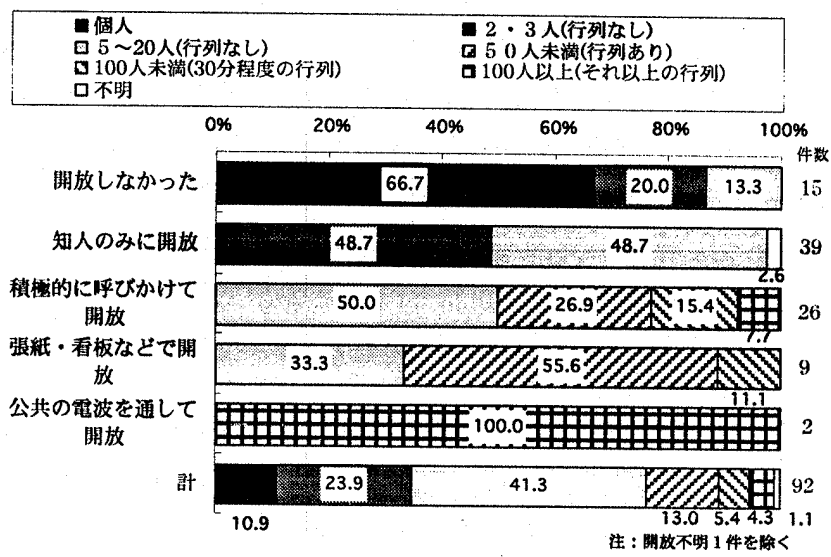

図-2 開放の仕方別利用範囲

表一 5 地区別利用時期

\begin{tabular}{|c|c|c|c|c|c|c|c|c|c|c|}
\hline & $\begin{array}{c}\text { 当日 } \\
(1 月 \\
17 日) \\
\end{array}$ & $\begin{array}{c}2 \cdot 3 \text { 日 } \\
\text { 後(18. } \\
19 \text { 日) }\end{array}$ & $\begin{array}{c}4 \sim 7 日 \\
\text { 後(20〜 } \\
24 \text { 日) } \\
\end{array}$ & $\begin{array}{c}\text { 1月 } \\
\text { 末 }\end{array}$ & $\begin{array}{l}2 \text { 月 } \\
\text { 上旬 }\end{array}$ & $\begin{array}{c}2 \text { 月 } \\
\text { 中旬 }\end{array}$ & $\begin{array}{l}2 \text { 月 } \\
\text { 下旬 }\end{array}$ & $\begin{array}{l}\text { 月月 } \\
\text { 上旬 } \\
\text { 以降 }\end{array}$ & 不明 & 計 \\
\hline 菅屋 & $\begin{array}{r}10 \\
(38.5)\end{array}$ & $\begin{array}{r}2 \\
(7.7)\end{array}$ & $\begin{array}{r}8 \\
(30.8)\end{array}$ & \begin{tabular}{r|}
3 \\
$(11.5)$
\end{tabular} & () & $\begin{array}{r}1 \\
(3.8)\end{array}$ & 0 & $\begin{array}{r}1 \\
(3.8)\end{array}$ & $\begin{array}{r}1 \\
(3.8)\end{array}$ & $\begin{array}{r}26 \\
(100.0)\end{array}$ \\
\hline 二革 & $\begin{array}{r}5 * \\
(50.0)\end{array}$ & $\begin{array}{r}3 \\
(30.0)\end{array}$ & $\begin{array}{r}1 \\
(10.0)\end{array}$ & 0 & $\begin{array}{r}1 \\
(10.0)\end{array}$ & () & 0 & 0 & 0 & $\begin{array}{r}10 \\
(100.0)\end{array}$ \\
\hline 須磨 & $\begin{array}{r}16 \\
(28.6) \\
\end{array}$ & $\begin{array}{r}10 \\
(17.9) \\
\end{array}$ & $\begin{array}{r}13 \\
(23.2) \\
\end{array}$ & $\begin{array}{r}4 \\
(7.1) \\
\end{array}$ & $\begin{array}{r}6 \\
(10.7) \\
\end{array}$ & $\begin{array}{r}2 \\
(3.6) \\
\end{array}$ & $\begin{array}{r}1 \\
(1.8)\end{array}$ & $\begin{array}{r}1 \\
(1.8)\end{array}$ & $\begin{array}{r}3 \\
(5.4) \\
\end{array}$ & $\begin{array}{r}56 \\
(100.0) \\
\end{array}$ \\
\hline 竍 & $\begin{array}{r}31 \\
(33.7) \\
\end{array}$ & $\begin{array}{r}15 \\
(16.3) \\
\end{array}$ & $\begin{array}{r}22 \\
(23.9) \\
\end{array}$ & $\begin{array}{r}7 \\
(7.6) \\
\end{array}$ & $\begin{array}{r}7 \\
(7.6) \\
\end{array}$ & \begin{tabular}{r|}
3 \\
$(3.3)$ \\
\end{tabular} & $\begin{array}{r}1 \\
(1.1) \\
\end{array}$ & $\begin{array}{r}2 \\
(2.2) \\
\end{array}$ & $\begin{array}{r}4 \\
(4.3) \\
\end{array}$ & $\begin{array}{r}92 \\
(100.0) \\
\end{array}$ \\
\hline
\end{tabular}

表ー6 井戸形式別井戸を利用し始めることができた理由

\begin{tabular}{|c|c|c|c|c|c|c|c|}
\hline & $\begin{array}{c}\text { 電気が } \\
\text { きたか } \\
5 \\
\end{array}$ & $\begin{array}{l}\text { フるベ・ } \\
\text { 手動ボン } \\
\text { ブにして }\end{array}$ & $\begin{array}{l}\text { 解体・ガ } \\
\text { レキを撤 } \\
\text { 去して }\end{array}$ & \begin{tabular}{c|} 
修理を \\
したか \\
5
\end{tabular} & その他 & 不明 & 敦 \\
\hline 手動ポンブ式 & 0 & $\begin{array}{r}6 \\
(46.2)\end{array}$ & $\begin{array}{r}2 \\
(15.4)\end{array}$ & $\begin{array}{r}1 \\
(7.7)\end{array}$ & $\begin{array}{r}2 \\
(15.4)\end{array}$ & $\begin{array}{r}2 \\
(15.4)\end{array}$ & $\begin{array}{r}13 \\
(100.0)\end{array}$ \\
\hline つるべ式 & 0 & $\begin{array}{r}4 \\
(66.7)\end{array}$ & $\begin{array}{r}1 \\
(16.7)\end{array}$ & 0 & 0 & $\begin{array}{r}1 \\
(16.7)\end{array}$ & $\begin{array}{r}6 \\
6100(0)\end{array}$ \\
\hline 鼠気モーター式 & $\begin{array}{r}29 \\
(44.6)\end{array}$ & $\begin{array}{r}14 \\
(21.5)\end{array}$ & $\begin{array}{r}1 \\
(1,5)\end{array}$ & $\begin{array}{r}1 \\
(15)\end{array}$ & 5 & 15 & 65 \\
\hline 不明 & 0 & $\begin{array}{r}3 \\
(37.5) \\
\end{array}$ & $\begin{array}{r}1 \\
(12.5)\end{array}$ & 0 & 0 & $\begin{array}{r}4 \\
(50.0)\end{array}$ & $\begin{array}{r}8 \\
(100.0) \\
\end{array}$ \\
\hline 計 & $\begin{array}{r}29 \\
(31.5) \\
\end{array}$ & $\begin{array}{r}27 \\
(29.3) \\
\end{array}$ & $\begin{array}{r}5 \\
(5.4) \\
\end{array}$ & $\begin{array}{r}2 \\
(2.2) \\
\end{array}$ & $\begin{array}{r}7 \\
(7.6) \\
\end{array}$ & $\begin{array}{r}22 \\
(23.9) \\
\end{array}$ & $\begin{array}{r}92 \\
(100.0) \\
\end{array}$ \\
\hline
\end{tabular}

\begin{tabular}{|c|c|c|c|c|c|c|c|c|}
\hline & 個人 & $\begin{array}{c}2 \cdot 3 人 \\
\text { (知人 } \\
\text { のみ) }\end{array}$ & \begin{tabular}{|c|}
$5 \sim 20$ \\
$\curlywedge$ \\
$($ 行列 \\
なし)
\end{tabular} & 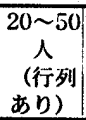 & $\begin{array}{c}50 \sim 100 \\
\text { 人(30分 } \\
\text { 程度の } \\
\text { 行列 })\end{array}$ & $\mid \begin{array}{l}100 人 \\
\text { 以上(そ } \\
\text { れ以上 } \\
\text { の行列) }\end{array}$ & 不明 & 計 \\
\hline 当日 & $\overline{3}$ & 8 & 14 & 4 & 0 & 2 & 0 & 31 \\
\hline (1月17日) & (9.7) & $(25.8)$ & $(45.2)$ & (12.9) & $(0.0)$ & (6.5) & & $(100.0)$ \\
\hline $2 \cdot 3$ 日後 & 0 & & & & 4 & () & 0 & 15 \\
\hline$(18 \cdot 19$ 日) & & (20.0) & (40.0) & (13.3) & (26.7) & & & $(100.0)$ \\
\hline 4〜 7 日後 & & 7 & 7 & 4 & () & () & 0 & 22 \\
\hline$(19 \sim 24$ 日) & (18.2) & (31.8) & $(31.8)$ & (18.2) & & & & $(100.0)$ \\
\hline 1月末 & & & & & 0 & ()) & 0) & 7 \\
\hline 2月上旬 & 0 & $\begin{array}{r}(42.9) \\
1\end{array}$ & $\begin{array}{r}(42.9) \\
3\end{array}$ & $\begin{array}{r}(14.3) \\
1\end{array}$ & 0 & 2 & 0 & $\begin{array}{r}(100.0) \\
7\end{array}$ \\
\hline & & (14.3) & (42.9) & (14.3) & & (28.6) & & $(100.0)$ \\
\hline 2月中旬 & & () & & 0 & 1 & ) & 0 & \\
\hline 以降 & $(50.0)$ & & $(33.3)$ & & $(16.7)$ & & & $(100.0)$ \\
\hline 不明 & & $\begin{array}{r}1 \\
(25.0)\end{array}$ & $\begin{array}{r}2 \\
(50,(0)\end{array}$ & 0 & 0 & 0 & $\begin{array}{r}1 \\
(25.0)\end{array}$ & $\begin{array}{r}4 \\
(100,0)\end{array}$ \\
\hline 矛 & $\begin{array}{r}10 \\
(10.9)\end{array}$ & $\begin{array}{r}23 \\
(25.0)\end{array}$ & $\begin{array}{r}37 \\
(40.2)\end{array}$ & $\begin{array}{r}12 \\
(13.0)\end{array}$ & $\begin{array}{r}5 \\
(5.4)\end{array}$ & $\begin{array}{r}4 \\
(4.3)\end{array}$ & $\begin{array}{r}1 \\
(1.1)\end{array}$ & $\begin{array}{r}92 \\
(100.0)\end{array}$ \\
\hline
\end{tabular}


震災後の利用用途をみると，各地区とも同じような傾向にある。 まずトイレ用には，ほとんどの井戸水が使われている。都市では水 洗トイレなので水は不可欠である。

さらに日々の生活の営みである炊事, 洗い物, 洗濯などの生活用 途にも広く使われている。飲料用に利用した人は $40 \%$ 弱で余り多く ない。これは，飲料用には「ペットボトル」など救援物資が使われ たことや井戸の水質も関係している。風吕への利用はほとんどな い。風呂には大量の水を必要とし，その余裕はなかったこと，利用 できたのは少数の条件がよかった層だけであったことを示してい る。同様に植木に利用する余裕もない。防火用水として活用された 井戸は事例が少ないが，大火災になる前にくい止めることができ重 要な役割を果たした。

また，水の再利用を心がけたという回答も多かった。まず炊事や 洗い物に，そして洗濯，最終的にトイレにといった具合である。 様々な工夫は，水がいかに貴重だったかを示している。

震災以前の利用用途と比べると，全く違った利用がされているこ とがわかる。震災以前は井戸はあまり積極的に使われていない。須 磨・芦屋地区では，植木や打ち水といった雑用水に，二葉地区では 豆腐屋や公旅浴場で利用されている。しかし飲料水や洗濯などに使 われている井戸もあり，水道が普及した現代でも地味ではあるが 細々と利用されていた。

\section{3、地区別にみる井戸の利用状況}

井戸の分布と震災後の利用範囲を地区別にみたのが図ー4〜図一 7 である ${ }^{3)}$ 。井戸の数は各地区によってばらつきがある。

\section{（1）芦屋地区}

芦屋地区は，須磨地区に次いで井戸が多い。使われていない井戸 もあわせると 82 個が残されている。そのうち震災後に利用された井 戸は2 6 個である。昔は各家に井戸が 1 個あるといわれるほどだった が, 他の地区と同様に滅少していた。

井戸分布と利用範囲（図一-4）をみると，井戸が散在しているこ とがわかる。中央の芦屋川より東側の公光町・大㭭町・茶屋之町等 に多く分布している。震災後，利用された井戸 26 個をみると，井 戸の少ない西側の方が利用範囲が大きい。井戸の多い東側は，個人 の利用や数人の利用が多い。また，以前から有名で多くの住民に利 用されていた井戸は，修理で利用時期が遅くなったにもかかわら ず, 再び多数の人に活用されている。

(2) 神楽地区

神楽地区は，ケミカルシューズ関連工場や店舗の多い地域であ る。準工業地帯であり，以前は沢山あった井戸も地下水の污染で急 激に減っていった。くまなく調查しても，更地が多く見つけやすい にもかかわらず発見できなかった。住民も井戸の存在をほとんど知 らなかった。利用された井戸は 1 個だけで，利用範囲も狭域である (図一 5 )

\section{(3) 二葉地区}

二葉地区の井戸は15 個で, うち 9 個の井戸が利用された。昔は井 戸が多く生活用水は井戸水が主であったが，空鼎による被害や水道 の普及, 開発の進行などで減少した。利用された 9 個のうち 8 個 は，商業用の井戸である。井戸の分布と利用範囲（図一 6 ）をみる と，数は少ないが 1 個当たりの井戸への利用集中度が高いことがわ
かる。とくに広箸囲に利用された井戸は，A， B の豆腐店とCのう なぎ屋の井戸である。この 3 個は利用していない人でも存在を知っ ているほどであった。3 個に共通して言えることは，元々商売に井 戸を使っていたこと, ラジオや張紙で積極的に知らせ, 開放したこ とである。そうした持主側の努力と善意が，広範囲に利用者を集め たといえる。そのほかの井戸も「個人の利用」や「知人のみに開 放」した井戸はなく，利用篹囲が広域であるのが本地区の特徽であ
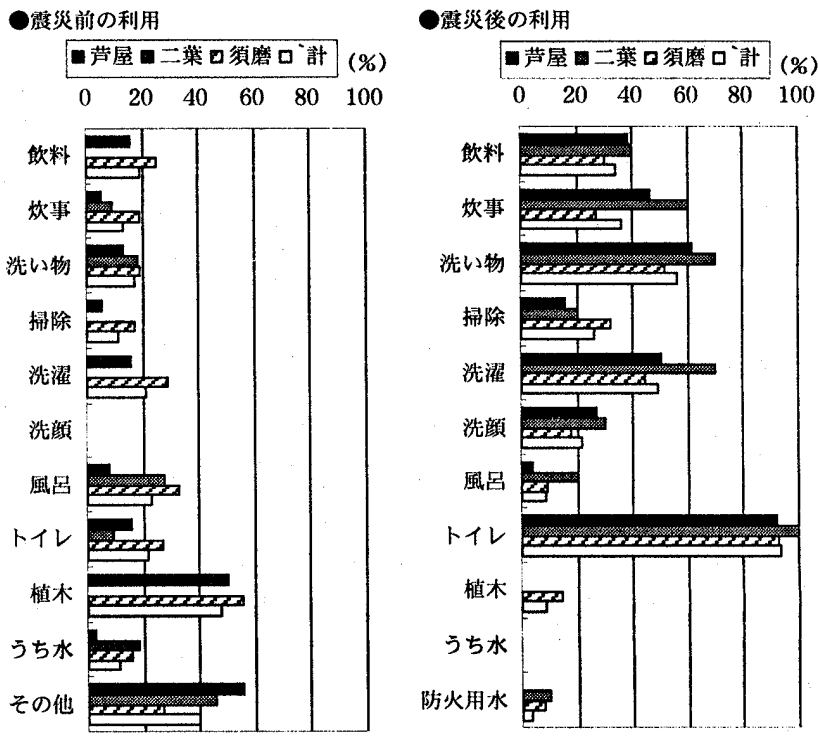

図-3＼cjkstart地区別にみた震災前後の井戸利用用途

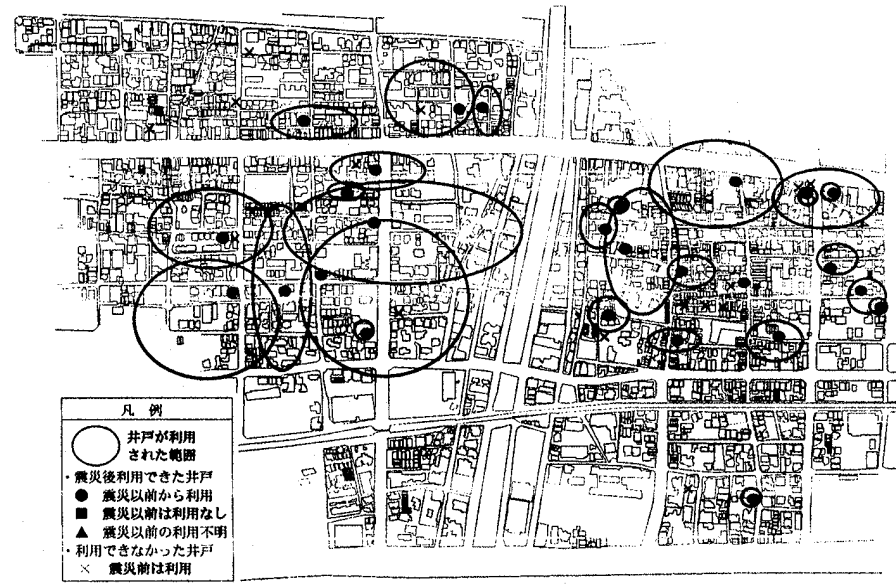

図-4＼cjkstart芦屋地区の井戸分布と利用範囲図

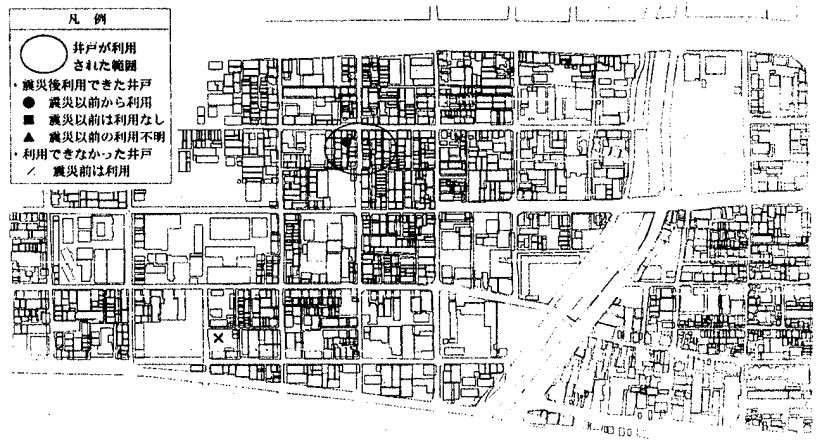

図一 5 神楽地区の井戸分布と利用範囲図 
る。

\section{（4）須磨地区}

須磨地区は，元々良好な住宅地で多くの住宅に井戸があったとい われている。家の建て替えや，水道の普及，山間部の開発による污 染などで徐々に井戸は埋められたが「井戸を潰すのは縁起が悪い」

「また使えるので残しておこう」などの理由で, 使っていなかった 井戸を含めて166個が残っていた。

利用された 56 個の井戸の分布と利用範囲 (図一 7) をみると,大半 の住民に水が行き渡ることが分かる。その中で広範囲に利用された 井戸が 2 個ある。1 個は北町にある浄徳寺の湧水（川の涌水で有 名，ほかに井戸 2 個も開放した）。もう 1 個は地区外になるが須磨 寺の冷泉である。この 2 ケ所は以前から有名で, 震災時も何百人を 越える人々が利用した。

そのほかの井戸でも積極的に開放された井戸もある。しかし個人 の井戸が多く，広範囲に利用された井戸は少ない。それでも周りの 住民は大いに助けられた。逆にいうと，周りに井戸がなかった住民 が有名な 2 ケ所の井戸を利用し，井戸が近くにあった住民はそちら を利用したことになる。しかし，場所によっては「井户なんて知ら ない」「井戸は家屋の倒壊で役にたたなかった」など，井戸を利用 しなかった住民も少なからずいた。とくに被害の大きかった南町で はこうした声が聞かれた。

さらに須磨地区では共同の井戸も特徵的である。宅地開 発した際, 街区隅部の敷地と道路の境界部分や路地内部に 設けており，興味深い事例となっている。

（5）地区による井戸分布の階層性

最も多いのは須磨で56個の井戸が利用されており突出し ている。次いで芦屋の 28 個である。それに比べ神楽では 元々 3 個で, そのうち 1 個が震災後に利用されただけで極 端に少ない。二葉も利用されたのは 9 個と少ない。今回の 震災では，被災・被害や住宅の再建について地域による階 層性が顕著に示されたことが特徵であったが，井戸についても長田 区は少なく，階層性が明確に表れている。

\section{4. 特徽的に利用された具体事例の分析}

以上が井戸の活用状況であるが，本章では特徵的に利用された具 体事例の分析を通して井戸の多面的な有効性を明らかにする。

（1）広範囲に利用された井戸(芦屋: 6 件, 二葉: 4 件, 須磨: 7 件)

行列ができるほど広範囲から利用されたのは, 住宅の井戸が 5 件, 商業用等の井戸が 12 件である。まず住宅で広範囲に利用された 例をみる。それは須磨地区の井戸で, 手動ポンプで元々植木の水に 利用していた。手動ポンブだったので当日から使うことができた。 持主は避難していたが, 片付けなどでよく家に戻ってきており，口 頭で周りの住民に呼びかけ，多いときで $7 \sim 10$ 人の行列ができてい た。近くの8 0 人程の避難所からもトイレの水としてよく汲みにき た。芦屋地区の例では，地震でポンプが井戸の中に落ちたが，つる べ式にして当日から利用できた。呼びかけは，家の全壊で用紙もな く，木の板に「飲み水ではありませんが, トイレの水などに自由に お使い下さい」と書き, 口頭でも呼びかけた。

商業用の井戸で, 最も広範囲に利用された例は 2 件ともラジオを 通して開放し，長い行列ができる程だった。トイレで水がなく图っ

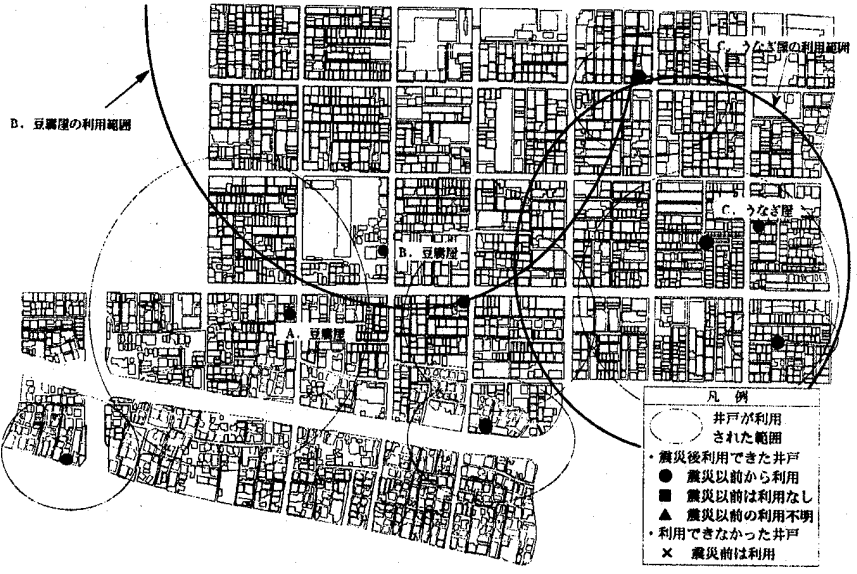

図-6 二葉地区の井戸分布と利用範囲図

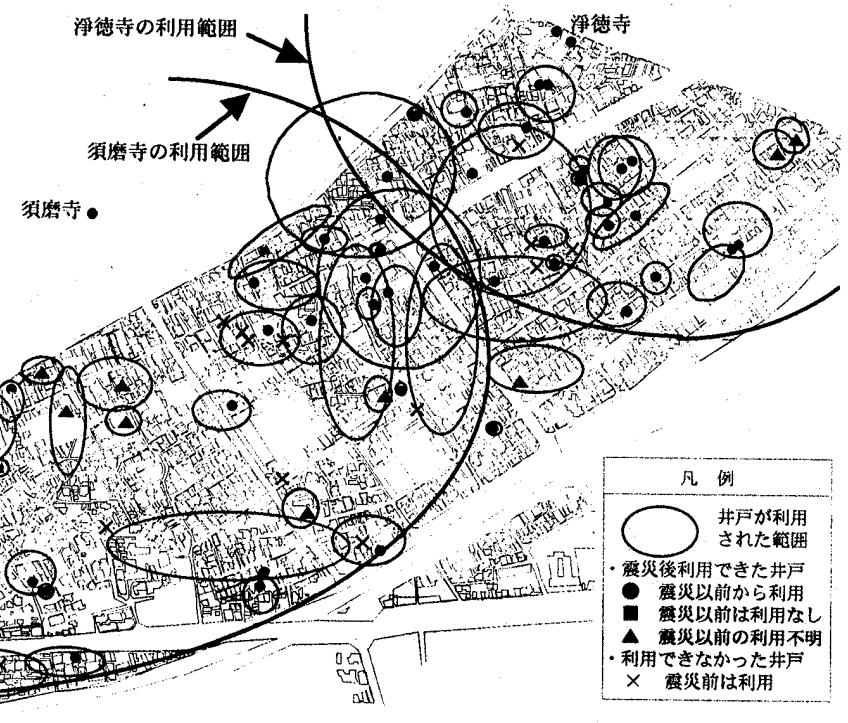

図-7 須磨地区の井戸分布と利用箸囲図

たので，みんなも困っているだろうと井戸水の開放を思い立ち，当 日の晚から開放し始めた。ストックしてあったポンブを使い，ホー スを外部に出して自由に利用できるようにした。呼びかけや市場の 入口の張紙などで積極的に開放した。数日後に利用者の 1 人がラジ オで「水あります」と報道してからは凄い人になり，市場の中まで $30 \mathrm{~m}$ の行列で 1 日 1000 人以上の利用があった。

（2）火災の消火に役立った井戸(芦屋: 2 件，二葉: 1 件)

芦屋地区の 1 件は, 当日に道路を挟んで 2 軒隣から出火したが, 消防車が来てこの井戸水で消火活動を行い，1２２軒燃えただけで 大火にならず消し止めることができた。また，つるべ式だったの で, 当日から井戸水を開放することができ, 多くの人に利用された （図－8）。芦屋地区のもう 1 件も当日レストランから出火した火 災で, 消防車が来るまで, 隣にあった井戸でバケッリレーを行い延 焼を防いだ。この火災では井戸だけでなく, 庭木も大きな役割を果 たした。隣のレストランが倒れてきたのを庭にあった一本の木が支 え，家は倒れず井戸も使うことができた。もしこの木がなかったら 井戸が利用できず，すぐに延焼してしまったであろう。井戸と木の 存在が大きな火災を防いだといえる。

二葉地区の例でも, 延焼を防ぐために井戸が利用された。本地区 では大火炎になり，一旦鎮火した後再びくすぶり出したときに前述 
した市場の井戸が利用され，他の 2 件とは違う形で役立っている。 また, 井戸ではないが, 芦屋で防火水槽が, 須磨で浄徳寺の湧水 (川の水) が，火炎の延焼をくい止めるのに役立っている。これら の共通点は, 井戸と火炎現場が近かったこと, もう一点はつるべ式 や手動ポンブであったため利用できたことである。

（3）炊き出しに利用された井戸(須磨: 2 件,芦屋: 1 件,二葉: 1 件) 須磨地区の例では, 浄徳寺の敷地内の空き地でボーイスカウトが 炊き出しを行っている。これは, 豊富な水（湧水・井戸水）があ り，炊き出しの拠点に選ばれたものとみられる。また元々商売をし ていた別の井戸では, 顔が広く $2 \sim 3$ 日後に電気がきた時から開放 し始めた。周辺住民に利用される一方で, 向かいの銀行の駐車場で の炊き出しにも使われている（図-9）。

二葉地区では，丸五市場でボランティアでなく住民自らが市場内 にある井戸を利用して炊き出しを行っている。また芦屋地区では, 避難所となっている集会所の前に井戸があり, 炊き出しに利用され ている。ここでは週 $1 \cdot 2$ 回ボランティアが炊き出しを行う程度 で，避難者による自炊はほとんどされなかった。

（4）洗濯機とともに開放した井戸(芦屋: 5 件,二葉·須磨:各1件) 今回の震災で特徵的だったことは洗濯機とともに開放した例で, 全地区で 7 件もあった。芦屋地区の商店の井戸の例では, 電気が来 たのが半月後でそれからの利用となった。洗濯機を 1 台置き，井戸 水とともに開放した。呼びかけは商売柄積極的で「飲み水以外にど うぞ」と呼びかけた。大通りに面していたこともあり多くの人が利 用した。しばらくして洗濯機をもらい，3台に増やして開放した。 利用者は多く，持主は夜中にやっと自分が使えるといった混雑ぶり だった。その後, 近くの津知公園にも洗濯機が設置されたことと, 最初の頃は水が非常に貴重で大切に扱ってくれたが，そのうち出 しっばなしにして䚻るなどマナーが悪くなってきたことから 2 月末 で開放を取りやめている（図-10）。

もう一つの事例では，周りの住民が困っているので何かしたいと 思ったのが洗濯機開放のきっかけであった。電気がきた震災 1 週間 後のことで, すぐ新しいポンブを購入し設置した。張紙をしたり, 洗濯機の横に大ダルをおきトイレや洗い水としても利用できるよう に工夫し，積極的に開放した。道路にあり目立つのと洗濯機も置い ていたので利用者は多く, 洗濯機はひつきりなしに動いていた。し かし，水をタルに貯めてあるので時間がかからず長い行列にはなら なかった。最初は電気を工場内から引いていたため平日の10〜17時 までしか開放できなかったが, 住民側から市に申し出をし，電柱か ら電気を引き一日中利用することができるようになった。そうした 住民の要望にも関わらず, 電気代がかかるという理由で 6 月には撒 去されている。

芦屋地区の例では，避難所となっている集会所があり，そちらに は市の方から洗濯機が提供され，向かいの井戸と共に開放され，避 難者と周りの住民に役立った。また，津知公園など，避難所にも洗 濯機が数台おかれていることろがあった。

（5）以前から有名な井戸(芦屋: 2 件, 須磨: 1 件)

以前から有名な井戸の 1 つは震災前からおいしい水として知られ た芦屋の井戸である。周りの住民はもちろん大阪や岐阜からも汲み にくるほどであった。この井戸は10 年前に皆に開放するのを目的に 掘ったもので, 持主はこの水は自然からの贈り物だと考えており,

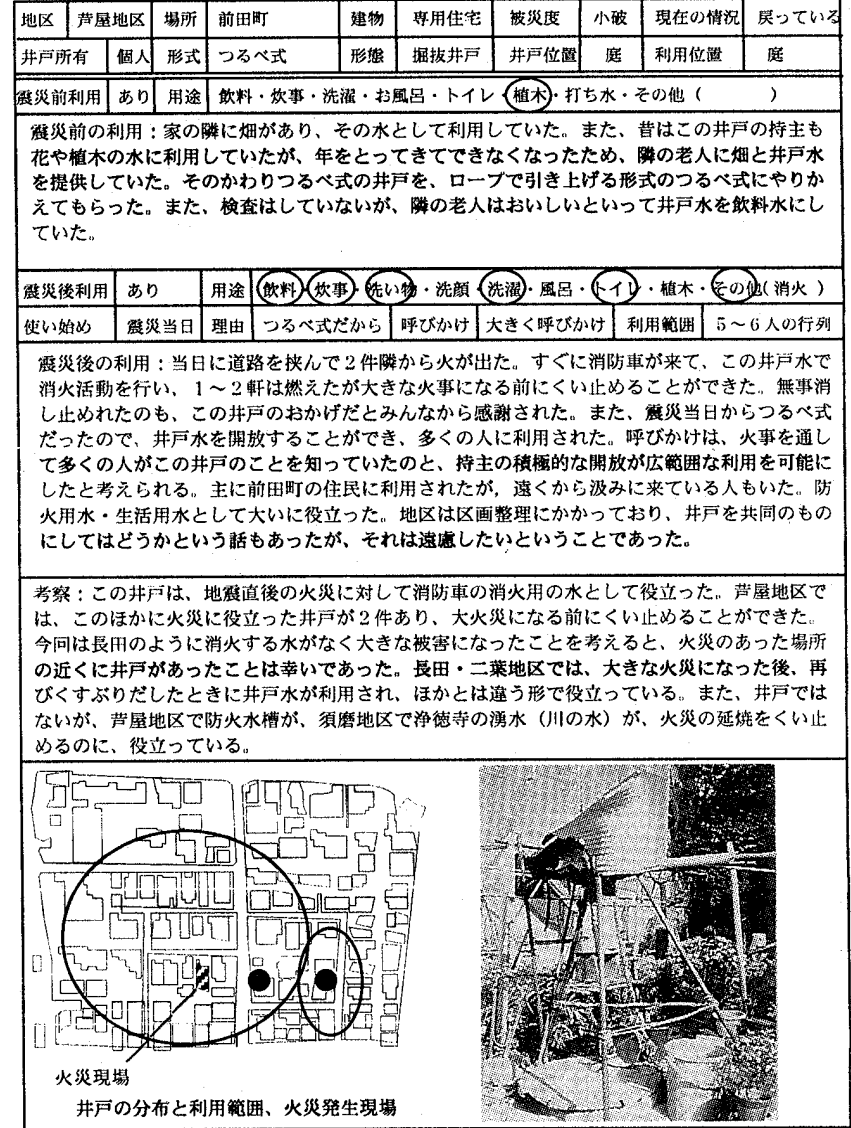

図-8 火災の 消火に役立った井戸

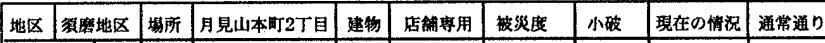
井戸所存 1 個人 1 形式

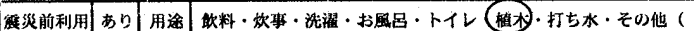
震災前の利用：花屋の井戸であり、震災前から花の水は全部井戸水でまかなっていた。また。 隣にカレ一屋があり，污の入口にも半户を引いており、条の手洗い用の水としても利用され ていた。

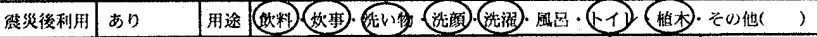

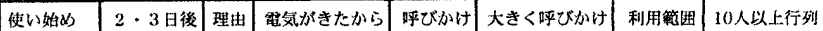
震災後の利用：2、3 日後に電気がきたので利用し始める。眘段は横の路地にある井户から淔 接くんでいたが、前の道路沿いまでホースを引っぱり、利用しやすくして開放した。㖘り組は していないか利用者は多く、元々韵売をしていたので顔が広く、幅広く呼びかけることがでさ

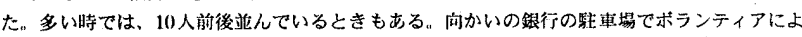
る炊きだしが行われ、その時の水としても大いに利用された。店は専用店舖だが、夜も利用て きるようにと電気をつけておいてくれた。また、一度ボンブが壊れてしまったが、向かいにあ る電気屋で割安ですくに直してもらい，近所で協力しあったことがわかる。主な利用者は月兒

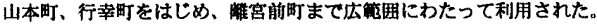

孝察 : この井戸は、他の井戸のように水を供給するだけでなく、跬車場での炏きだしにも利用 された。これは、水があったから炊きだしのときに撄点になったのか、たまたまそうなったの かはわからないが、トラブルなども一切なく、井戸の持主も好意的に開放している、また、商 党をしていて顔が広かったので法笔囲に利用されたことも、井戸が大きな役割を果たしたとい える。

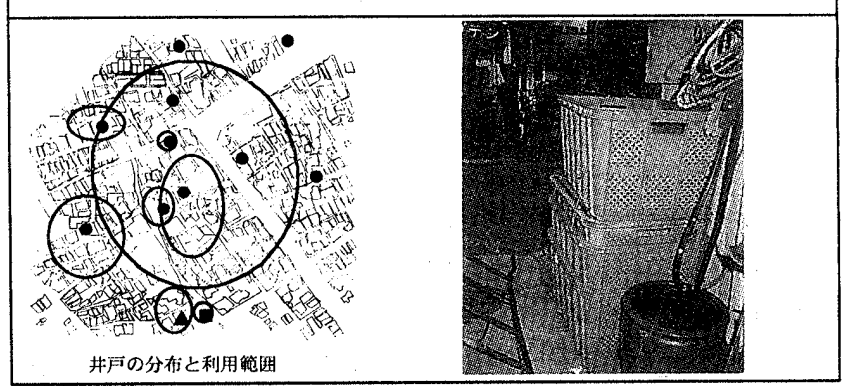

図-9 炊き出しに利用された井戸 
積極的に開放していた。ほとんどの周辺住民がポリタンクやペット ボトルに入れて家に常備し，なくなりかけると汲みにきていた。ま た何年おいても腐らない魔法の水だと言われており，1日400人〜 1000 人の利用があった。

地震で井戸が壊れモーターも故障し，井戸を修理したり新しいポ ンブを購入をする等して，なんとか 3 月中旬に利用できるように なった。それからは24時間開放し，周りの住民や今まで知らなかっ た人たちも列をなしていた。住民の中には，しばらくこの水を飲め なかったので体が不調だという人もいた。いかにこの水が地域住民 にとって大事な存在になっていたかがうかがえる。前述したよう に，この井戸水をためおきしている住民が多く，震災 1 ・ 2 日はそ の水で何とか凌ぐことができたという。また，ためおき用に，ポリ タンク等を最低 $1 \cdot 2$ 個は持っており,それが給水車から水をもら う際に役立っている。

普段からの水への関心の高さがこうした災害にもすぐに対応でき たわけで，一つの教訓といえる。震災以前からこの井戸の持主は, 水に注目し井戸を守っていこうと市などにも訴えていた。今回の震 災を通してその考えはより強まり，井戸の保存と各町に良い井戸を 掘って，普段から開放することを提案している。

また, 須磨地区では須磨寺の井戸水が以前から有名で, 震災直後 から500 人以上の行列ができるほど利用された。須磨寺側も水量を 考え，10ヶ所ある蛇口を表の 2 ケ所にして開放した。

（6）共同の井戸(須磨: 5 件，芦屋: 1 件)

共同の井戸は須磨地区の南町 2 丁目でみられた。昔の宅地開発に ともなってつくられ, 路地のなかや街区交点の敖地境界部にあり, 道から使えるようになっている。3 個の共同井戸は，つるべ式で散 水や植木の水として利用されていた。また1 個は枯れていたが井戸 を埋めるのは縁起が悪いということで残していた。

震災後は，まわりの住民（ほとんどが以前から利用していた）が 利用したが，元々水質があまりよくないためトイレの水くらいにし か利用できなかった。そのうちの 1 個の井戸は, 震災 1 年後, 持主 が敷地を売ることになり，周りの住民の井戸を残そうとする動きも あったが，話し合いがつかないうちに，業者に埋められてしまうと いう残念な結果になった（図-11）。

南町 2 丁目に共同井戸が多い理由は, 住民の話では, 戦時中に地 主が何かあった時のために掘ったということである。貴重な教訓で あり，できるだけ残していく必要があるだろう。今後の防災を考え たとき, 井戸の保存・維持管理も重要である。

\section{5 . 蹗災後の井戸活用や井戸つくくり対策の動向}

震災後井戸の重要性が再評価され，その活用を図るための方策やま ちづくり等で井戸をつくるという新しい動きがみられる。ここではそ うした動向について神戸市を中心に考察する。

井戸活用の方策は, 第一には, 災害時に市民に開放する井戸の登録 制度である。神戸市では, 平成 $8 \sim 10$ 年に井戸の登録制度を行った。 応募は 586 件で, 内登録できたのは 542 件であった（表一 8 ）。登録 できなかったのは, 水の変色, 水量不足や応募すれば井戸を掘ってく れると誤解した場合などである。また，井戸があるのに登録しない ケースは，普段から使われるのはいや，名前をオーブンにしたくな い, 役所に言うと管理されてしまうといった理由である。登録数と実

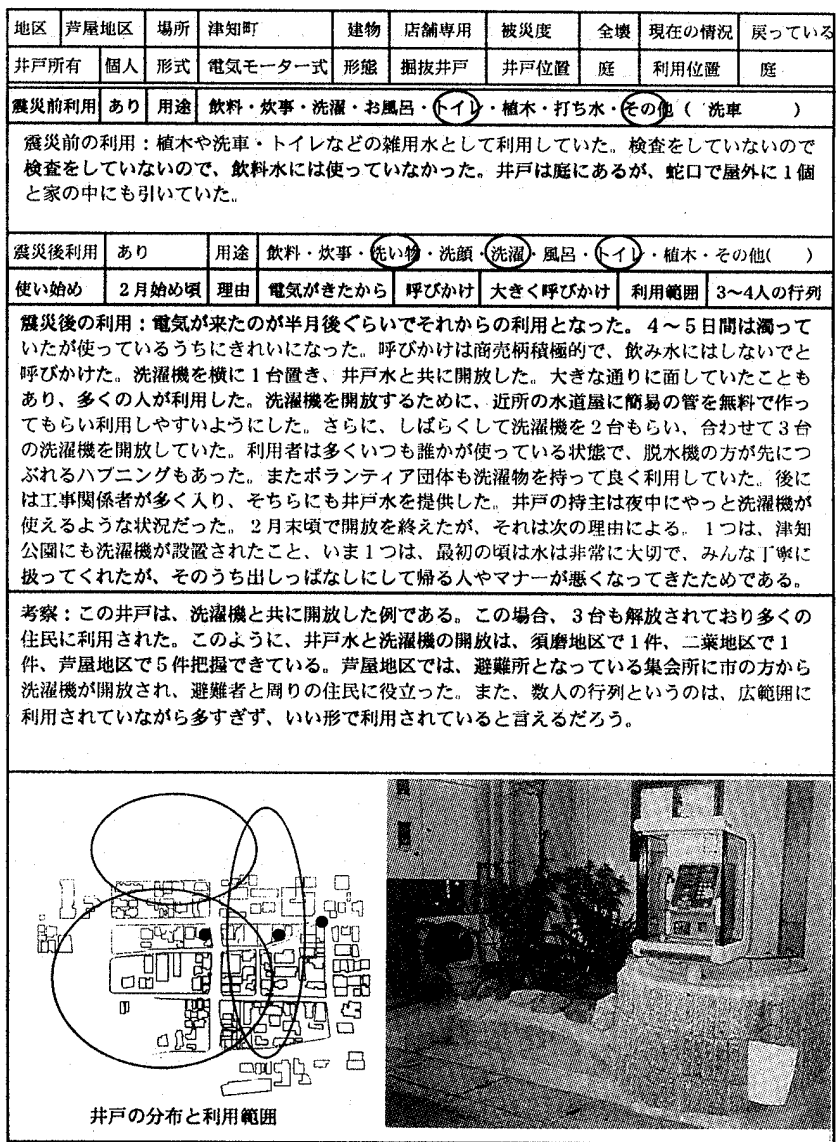

図-10 洗濯機とともに利用された井戸

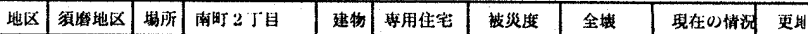

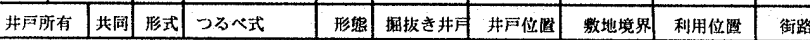

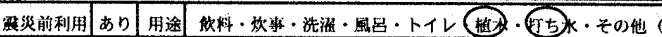

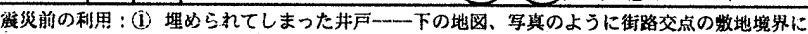
あり、道路側から便えた。近所の $4 、 5$ 軒が、各々つるベ (ローフつきのバケツ) をもってい て、打ち水や植木に使っていた

(2) 朔いてきた井戸一-一元々道路にある井戸であり、枯れていたため利用していなかった。しか し、軽めるのは緣起が悪いというので残していた。そして每月1日、15日に找供えをしてい

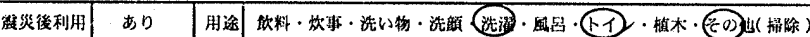

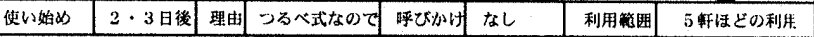

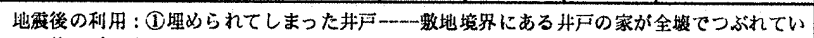
て、使いつらくく、当日からは利用できなかった。あままきれいな水ではなかったため、家县を ふくのに使ったり、主にはトイレの水に使った。元々 $4 、 5$ 軒て利用していたのて、呼ひかけ もせず、その人たちが使ったようである。地㿑後、この家の敖地が艽りにだされ、井户を埋め る、埋めないで業者と周りの住民の間に対立が少しあったが、話し合いのつかないまま埋めら る、埋めないで

れてしまつた。

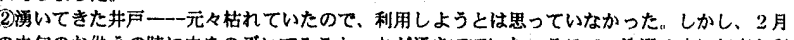
の中向のお供えの時に中をのぞいてみると、水が湧きでていた。そこで、洗濯の水に何度か利 用した。気づいたのが随かったのて、解放もしなかった。

孝察：续唐地区の南町 2 丁目には、この井戸を含め 4 倜の共同井戸がある，以前は共同井戸が もう1固あったが、今は数地内にあって個人の井声として使われている。どうしてこのエリア

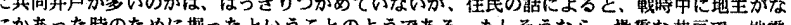
等

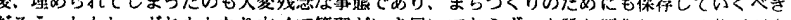

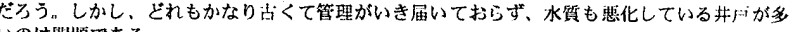
いのは問頡である

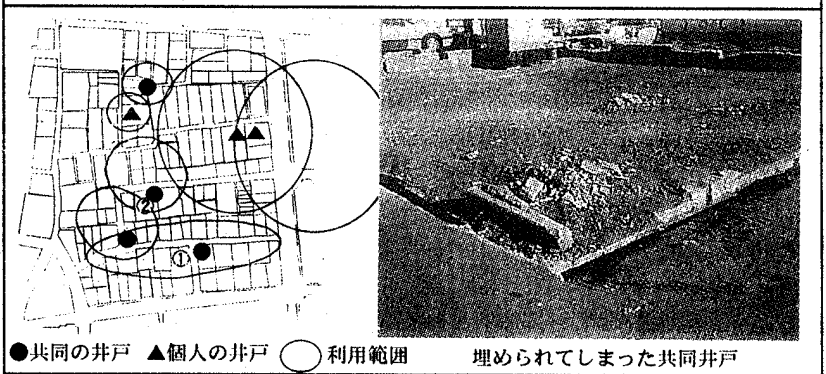

図-11 共同の井戸(埋められてしまった井戸，湧いてきた井戸) 
際の井戸の数との関係はわからないが, 今回の須磨の調査対象地区で みる限りでは, 私たちの調査での「震災後利用された井戸」56個に対 して，調査区域内で登録されている井戸は 17 個だけであった。

神戸市の登録数をみると, 東灘, 灘区などの東部に多く, 都心部の 中央区やニュータウンの西区に少ない。また，調査では須磨に多く， 長田に少なくなっていたが，区全体の登録数では長田区の方が多い。 登録制度の現在の問題点は，予算のほとんどが，水質検査にとられ， しかも飲料不適が圧倒的に多いこと, 登録者への財政的補助・助成が ないことである。

井戸の登録制度は東京都世田谷区, 横浜市等では震災のかなり以前 から行われている。世田谷区では昭和 58 年に要綱をつくり「災害対 策用井戸」として現在 2100 件が登録している。助成条件は, (1)看板 を揭出してもらう, (2)年 1 回の水質検査, (3)消毒液の配布（2年に 1 回）である。さらに現在ある井戸にポンプを設㯰する場合には，(1)か かった費用の 2 分の 1 で, (2)限度額 10 万円までという条件で補助を 行っている。世田谷区では,これまで井戸を飲料水として考え水質検 查を行ってきたが, それを生活用水にするよう要網を改正しようとし ている。理由は費用をかけて水質検查をしても $60 \%$ が不適であり, そ の一方で給水槽の設置で区民一ヶ月程度の備蓄ができたこと,阪神大 震災で飲料水より生活用水が大量に必要であることが明らかになった ことによる。

第二に, まちづくり等で井戸づくりの試みが動きだしたことである。 しかし，その実態は行政のある部署で一括して把握しているといった ことはなく, 設置主体も行政だけとは限らない。表一 9 は，神戸市で 公園に井戸を設置している事例であるが, 身近な街区公園を中心に設 圆されている。公園と学校グラウンドとの併設もみられる。すべての 事例が震災以降の取り組みである。東京などでは, 震災以前から, ま ちづくりのなかで雨水等を利用した井戸づくりが行われていたが, 井 戸の登録制度と同様,こうした地味な分野では, 彼我の取り組みの差 は非常に大きいことがわかる。

\section{6. まとめ}

本論文を要約的にまとめると以下のようになる。

(1) 阪神·淡路大震災で都市ストックとして井戸が果たした役割は大 きかった。対象 4 地区の調查で震災後利用できた井戸は 92 個であっ た。須磨, 芦屋で多く, 長田, とくに神楽地区では 1 個だけであった。 井戸でも被災·復興と同㥞階層性がみられた。

(2) 利用範囲は, 数人の利用から行列をつくる広範な利用まであり, とくに商業用の井戸では広範囲から利用されている。また自分だけで 使った井戸はほとんどなく，大部分の井戸が開放され，贵重な生活用 水として役立っている。

（3）利用時期は, 震災後 1 週間以内で 7 割の井戸が利用し始めてい る。主力である電動モーター式は, 電気が来ないと使えないわけで, 手動ポンブ式やつるべ式が力を発揮している。利用用途は, 生活に不 可欠なトイレの水に大部分の人が使っている。次いで炊事, 洗い物, 洗濯である。飲料用は 4 割と以外に少なく，風呂や植木に使う余裕は ない。

（4）特徵的に使われた事例からは，井戸の多面的な有効性が明らか にできた。それらは，防火用水として役立った井戸，炊き出しに利用 された井戸，洗濯機とともに開放した井戸，以前から有名だった井
表-8 災害時市民開放井戸区別登録件数

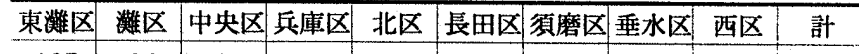

\begin{tabular}{|c|c|c|c|c|c|c|c|c|c|}
\hline 125 & 96 & 14 & 64 & 82 & 50 & 40 & 56 & 15 & 542 \\
\hline
\end{tabular}

（資料）神戸市保健衛生部，平成13年 3 月末現在

表-9 井戸を設置している公園

\begin{tabular}{|c|c|c|c|c|}
\hline $\bar{区}$ & 公園名 & 種別 & 面積 $\left(\mathrm{m}^{2}\right)$ & 特徵 \\
\hline \multirow[t]{3}{*}{ 東灘区 } & 川井公園 & 近隣 & 10,760 & 手押しポンプ \\
\hline & 森公園 & 街区 & 5,078 & 手押しポンプ \\
\hline & 住吉本町公園 & 街区 & 2,719 & 手押しポンプ \\
\hline \multirow[t]{2}{*}{ 灘区 } & 成德公園 & 街区 & 3,114 & 手回しポンプ，学校隣接·共用 \\
\hline & 岸地通公園 & 街区 & 1,000 & 手押しボンプ \\
\hline \multirow[t]{2}{*}{ 兵㢆区 } & 五宮町公園 & 街区 & 7,000 & 手押しポンプ \\
\hline & 先田公園 & 近隣 & 27,593 & 手押しホンンフ(雨水利用) \\
\hline \multirow[t]{3}{*}{ 長田区 } & 新潜川公園 & 近䇬 & 20,988 & 手押しボンブ \\
\hline & 神楽公園 & 街区 & 3,099 & 手押しボンブ \\
\hline & 高東町公園 & 都緑 & 6,000 & 手押しボンプ(雨水利用) \\
\hline \multirow[t]{3}{*}{ 須磨区 } & 天井川公園 & 街区 & 2,719 & ソーラーポンプ \\
\hline & 若宮公園 & 街区 & 1,333 & 手押しポンプ, 学校隣接·共用 \\
\hline & 昮浜公園 & 総合 & 139,545 & 踏み台ボンブ(雨水利用) \\
\hline 北区 & 広陵公園 & 街区 & 5,055 & 手押しボンブ(雨水利用) \\
\hline
\end{tabular}

（資料）神戸市公園管理諜, 平成13年 3 月末現在

戸, 共同の井戸などである。今回, 調査するまで井戸水とセットで洗 濯機が開放されたことは予想していなかったが，緊急時に住民同士 が助け合う姿がよく分かる。しかし，市からの提供等は少なく，自 分たちで洗濯機を開放しており，行政が井戸のあるところに 1 台ず つ支援する等の方策が今後の教訓となる。

(5) 震災後の取り組み, 対策として井戸の登録制度やまちづくり等 で井戸をつくる試みが始められている。東京などと比べるとまだ端 緒的であるが今後の方向について述べたい。(1)井戸の登録を増やす こと，そうした分野こそ助成が必要である。(2)小居住地単位のまち づくりで水や緑とともに井戸をつくっていくことは，遊び心のある 小道具としても環境共生や自然を知る教育機能としても重要である。 (3)非常時よりも日常的に庭の植木への水やリ，打ち水，おしゃべり などでそうした空間が利用されればコミュニティの活性化につなが る。(4)非常時のためには個人, 企業, 学校, 地域, 公共期間等が保 有する井戸がまちづくりマッブ, 地域マップでデータベースとして 把握できるようにすること，等である。

（6）今まで蛇口をひねれば水が出るという当り前のことが, 今回の 震災で見事に覆された。しかし，皮肉なことにこうした状況になる まで，井戸の存在は軽く扱われてきた。井戸やそれを含めた自然を 今こそ見直していく必要がある。そうした価値観の転換こそ，防災 都市づくり・豊かなまちづくりへつながるのである。

本調査は当時の卒論生山口昌子とともに行ったものである。記し て感謝したい。

\section{脚注}

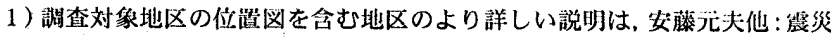
前の木造密集市街地の実㲘と被災による建物・住宅被害の構造に関する研究, 日本建築学会計画系論文集 第 520 号, 1999 年 6 月, を参照のこと。 2) 调查では，更地でも「井户」の形態が碓認できたものは対象とした。その ため、震災前の利用不明には，廃萧されていたものもあると考えられる。 3）问心円表記の利用笔国はヒアリングによる「概ねの利用範用」である。 